\title{
Primary clear cell adenocarcinoma of vagina - not associated with diethylstilbestrol exposure
}

\author{
Sumanta Bhattacharya ${ }^{1}$, Sujoy Dasgupta ${ }^{2}$, Soumyakanti Pramanik ${ }^{1}$, Prithwijit Ghosh ${ }^{3}$
}

\author{
${ }^{1}$ Department of Pathology, IPGMER/SSKM Hospital, Kolkata, West Bengal, India \\ ${ }^{2}$ Department of Obstetrics and Gynaecology, GIMSH, Durgapur, West Bengal, India \\ ${ }^{3}$ Consultant Pathologist, GDDI Hospital, Kolkata, West Bengal, India
}

Received: 13 September 2016

Accepted: 08 October 2016

\author{
*Correspondence: \\ Dr. Sujoy Dasgupta, \\ E-mail: dr.sujoydasgupta@gmail.com
}

Copyright: () the author(s), publisher and licensee Medip Academy. This is an open-access article distributed under the terms of the Creative Commons Attribution Non-Commercial License, which permits unrestricted non-commercial use, distribution, and reproduction in any medium, provided the original work is properly cited.

\begin{abstract}
The primary clear cell adenocarcinoma (PCCA) of the vagina and the cervix are commonly associated with in utero exposure to diethylstilbestrol (DES). However, it can occur without DES exposure in utero. Due to rare occurrence, there is paucity of data on the literature on non-DES associated PCCA of the vagina. Here we describe a case of 45 years old woman presented with irregular vaginal bleeding with small nodule in the vagina. The growth was excised and sent for histopathological examination, after which the diagnosis turned out to be a case of PPCA of the vagina. After the diagnosis, definite treatment was planned in the form of hysterectomy and pelvic lymphadenectomy and all structures were free of tumour on histopathological examination. The patient remained disease free on short term follow up. The rarity of the occurrence of such a case of PPCA of vagina in Indian scenario and the uniqueness of it in terms of non-association with DES exposure prompted us to report this case.
\end{abstract}

Keywords: Cervix, DES, PCCA, Vagina

\section{INTRODUCTION}

The primary clear cell adenocarcinoma (PCCA) most commonly involves cervix, vagina, endometrium ovaries and urinary tract including kidneys. It accounts for 5-10\% of all vaginal malignancies. ${ }^{1}$ Ultra structurally and immunologically, vaginal and cervical clear-cell adenocarcinomas are identical to clear-cell adenocarcinomas that arise in the ovary or endometrium. ${ }^{2}$ The association of vaginal and cervical clear-cell adenocarcinoma with in utero exposure to diethylstilbestrol (DES) is well known, but up to onethird of patients lack exposure. ${ }^{3}$ From 1938 until 1971, DES was used to prevent miscarriages. But, it was withdrawn worldwide by FDA due to its proven role in carcinogenesis. ${ }^{4}$ More than 700 cases of vaginal and cervical clear-cell adenocarcinoma have been accessioned in the Registry for Research on Hormonal Transplacental Carcinogenesis. ${ }^{5}$ Literature lacks information regarding clinical behavior, pathology and prognosis of non-DESassociated primary clear cell carcinoma of the vagina (PCCAV) as they are rare. The purpose of the study was to report a case of non-DES-associated PCCAV in our effort to further improve the biological characteristic of these rare tumours in terms of prognosis.

\section{CASE REPORT}

A 45 years old woman presented with irregular vaginal bleeding and discharge. She had history of two vaginal deliveries; last one is 20 years back. There is no history suggestive of DES exposure to patient or her mother. Per abdominal examination was unremarkable. The ultrasound report of whole abdomen was inconclusive and kidney, urinary bladder and urethra region was within normal limit. There was a small nodular growth on vagina involving anterior wall, measuring $0.5 \mathrm{~cm}$ in maximum diameter. On the basis of history and 
examination the following differential diagnosis were made: 1) infected fibroepithelial polyps, 2) leiomyosarcoma of vagina, 3) Metastasis from unknown primary.

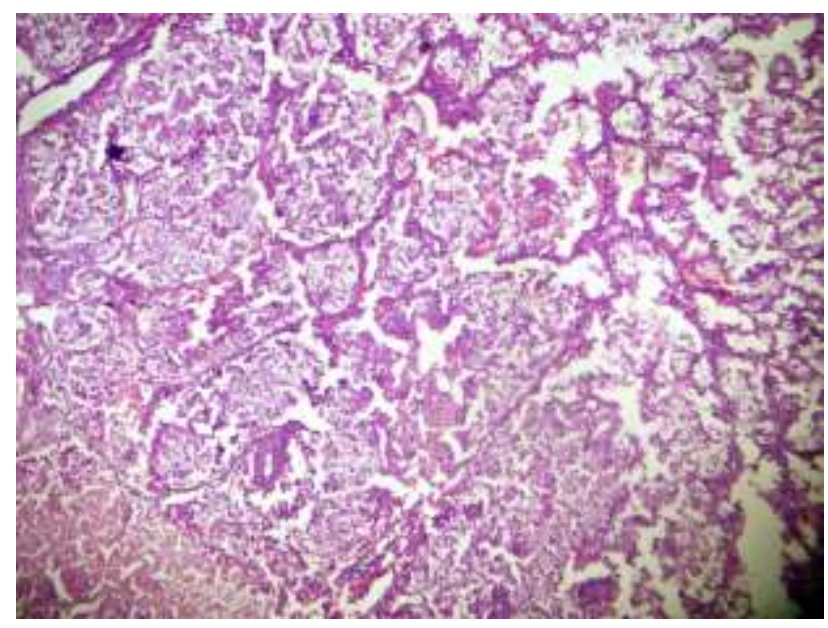

Figure 1: Routine section shows sheets of tumor cells having clear cytoplasm with vesicular nuclei, separated by fibrovascular stroma (H/E, x40).

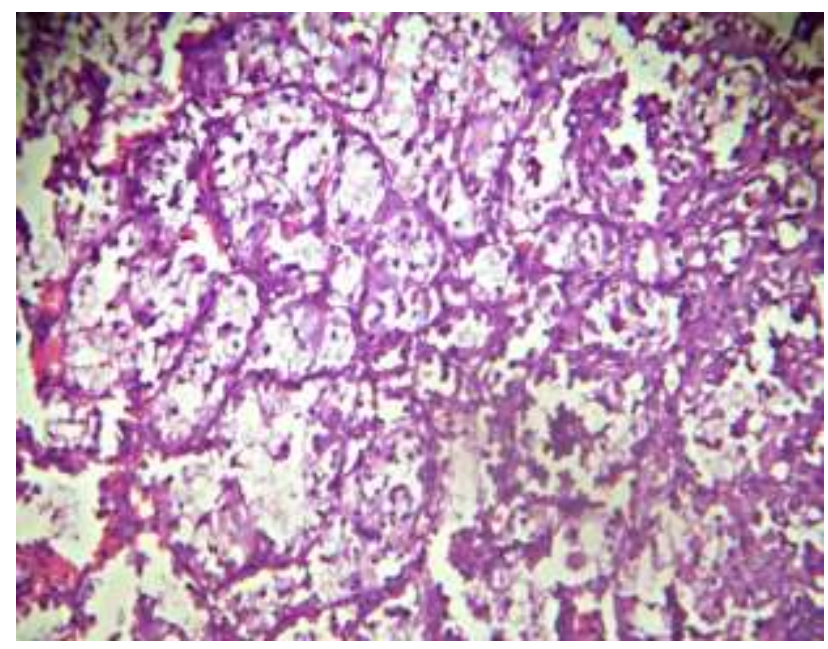

Figure 2: Routine section shows sheets of tumor cells having clear cytoplasm with vesicular nuclei, separated by fibrovascular stroma (H/E, x100).

Patient underwent polypectomy. Grossly it was sent to laboratory as multiple bits of friable tissue. On microscopic examination and Hemotoxylin/Eosin staining, a polypoidal tissue showed a tumor mass composed of confluent nests and sheets of cells having abundant clear to eosinophilic cytoplasm, separated by fibrovascular stroma (Figure 1). The cells had vesicular nuclei with prominent nucleoli, at places with nuclear inclusion and hobnailing (Figure 2). Large areas of necrosis were also seen. The cells showed positive reaction of cytoplasm on staining with Periodic-Acid Schiff stain. Based on these features a diagnosis of Primary clear cell adenocarcinoma of vagina was made.
Following the diagnosis hysterectomy was done along with removal of pelvic lymph nodes. On histopathological examination, all of these structures were within normal limits and no residual tumor or metastasis was detected. On follow up after two months the patient is doing well and the bleeding disorder has not recurred so far.

\section{DISCUSSION}

The patients range in age from 7 to 37 years, and the median age is 19 years at diagnosis. These tumours had a bimodal age distribution, the first peak occurring at a mean age of 26 years and second peak of median age of 31 years. $^{6}$ Genetic instability, identified by somatic mutation of microsatellite repeats, has been found in these neoplasms, whereas mutations in p53, K-ras, the Wilms tumor (WT1) tumor suppressor gene, and the estrogen receptor gene have been absent. ${ }^{7}$ Abnormal vaginal bleeding, discharge, dyspareunia and vaginal mass are the most common presentations. Grossly, the neoplasm appears as a polypoid, nodular, flat, or ulcerated mass, usually in the anterior or lateral wall of the upper vagina. Rarely, it is confined to the lamina propria with overlying normal squamous epithelium. Clear-cell adenocarcinoma varies in size from microscopic to more than $10 \mathrm{~cm}$ in diameter. ${ }^{8}$ Microscopically, about $60 \%$ of cervical and vaginal tumors show a predominantly tubulocystic growth pattern; $20 \%$ have a predominantly solid pattern of growth, and $12 \%$ are papillary. A mixture of growth patterns is usual. Solid sheets of tumor are composed of cells with abundant clear cytoplasm. Tubules, cysts, and papillae are lined chiefly by cells that are cuboid, hobnail, or flat. Cords of cells having eosinophilic cytoplasm also may be observed. Nuclear pleomorphism is variable. Flat cells that line dilated cysts often have a bland cytologic appearance. Approximately three-fourths of all neoplasms have no more than 1 mitotic figure per 10 hpfs. Foci of atypical adenosis usually are observed adjacent to the tumor, though this was absent in our case. ${ }^{8}$ The cells of the tumor show positivity for periodic acidSchiff (PAS) stain due to presence of glycogen in their cytoplasm. This glycogen content is responsible for clearing of the cytoplasm. ${ }^{9}$ The characteristic immune profile of PCCA of the genitourinary tract for all sites is CK7, CAM5.2, 34 beta E12, CEA, CA-125, Leu-M1 and vimentin positive. $^{10}$

Non-DES-associated PCCA of the vagina and cervix may also be related to adenosis and other congenital malformations such as didelphys uterus with a double vagina, renal agenesis and situs inversus. ${ }^{11}$

Non-DES-associated PCCAV has a poor prognosis and significantly worse outcomes than those seen in patients with other primary carcinomas of the vagina. Local and distant recurrence rates are also more common among these patients than patients with squamous cell carcinoma who have received similar treatment. ${ }^{12}$ Nordiqvist et al 
reviewed twenty one cases of vaginal and cervical clear cell adenocarcinomas, out of which thirteen had no prior exposure to DES. ${ }^{13}$

We take this opportunity to report this unique and relatively rare case of Primary clear cell adenocarcinoma of vagina-not associated with DES therapy in Indian scenario.

\section{ACKNOWLEDGEMENTS}

The authors are grateful to all the faculty members and staffs of Department of Pathology and Department of Pathology and Department of Obstetrics and Gynaecology, IPGMER for their cooperation while collecting the case details.

Funding: No funding sources

Conflict of interest: None declared

Ethical approval: Not required

\section{REFERENCES}

1. Guzin K, Eser SK, Yigit A, Zemheri E. Primary clear cell carcinoma of the vagina that is not related to in utero diethylstilbestrol use. Gynecol Surg. 2006;3:281-4.

2. Vang R, Whitaker BP, Farhood AI, Silva EG, Ro JY, Deavers MT. Immunohistochemical analysis of clear cell carcinoma of the gynecologic tract. Int $\mathrm{J}$ Gynecol Pathol. 2001;20:252-9.

3. Jefferies JA, Robboy SJ, O'Brien PC, et al. Structural anomalies of the cervix and vagina in women enrolled in the Diethylstilbestrol Adenosis (DESAD) Project. Am J Obstet Gynecol. 1984;148:59-66.

4. Selected item from the FDA drug bulletin. November 1971: diethylstilbestrol contraindicated in pregnancy. Calif Med. 1972;116:85-6.

5. Robboy SJ, Taguchi O, Cunha GR. Normal development of the human female reproductive tract and alterations resulting from experimental exposure to diethylstilbestrol. Hum Pathol. 1982;13:190-8.

6. Senekjian EK, Hubby M, Bell DA. Clear cell adenocarcinoma (CCA) of the vagina and cervix in association with pregnancy. Gynecol Oncol. 1986;24:207-19.

7. Boyd J, Takahashi H, Waggoner SE. Molecular genetic analysis of clear cell adenocarcinomas of the vagina and cervix associated and unassociated with diethylstilbestrol exposure in utero. Cancer. 1996;77:507-13.

8. Ray J, Ireland K. Non-clear-cell adenocarcinoma arising in vaginal adenosis. Arch Pathol Lab Med. 1985;109:781-3.

9. Knez VM, Barrow W, Lucia MS, Wilson S, La Rosa FG. Clear cell urothelial carcinoma of the urinary bladder: a case report and review of the literature. Journal of Medical Case Reports. 2014;8:275.

10. Frank SJ, Deavers MT, Jhingran A, Bodurka DC, Eifel PJ. Primary adenocarcinoma of the vagina not associated with diethylstilbestrol (DES) exposure. Gynecol Oncol. 2007;105:470-4.

11. Zeeshan-ud-din, Ahsan A. Vaginal clear cell adenocarcinoma with associated Müllerian duct anomalies, renal agenesis and situs inversus: report of a case with no known in-utero exposure with diethyl stilboestrol. J Pak Med Assoc. 2009;59:56870 .

12. Senekjian EK, Frey KW, Anderson D, et al. Local therapy in stage I clear cell adenocarcinoma of the vagina. Cancer. 1987;60:1319-24.

13. Nordqvist SR, Fidler WJ Jr, Woodruff JM, Lewis JL Jr. Clear cell adenocarcinoma of the cervix and vagina. A clinicopathologic study of 21 cases with and without a history of maternal ingestion of estrogens. Cancer. 1976;37:858-71.

Cite this article as: Bhattacharya S, Dasgupta S, Pramanik S, Ghosh P. Primary clear cell adenocarcinoma of vagina - not associated with diethylstilbestrol exposure. Int J Reprod Contracept Obstet Gynecol 2016;5:4061-3. 